\title{
NO DOCUMENTABLE ROLE FOR XANTHINE OXIDASE IN THE PATHOGENESIS OF HEPATIC IN VIVO ISCHAEMIA/REPERFUSION INJURY
}

\author{
GIULIANA CIGHETTI, SANDRA DEBIASI and RITA PARONI $†$ \\ Department of Medical Chemistry and Biochemistry, University of Milan, and \\ $\uparrow$ Scientific Institute San Raffaele, Milan, Italy \\ Received in final form 21 May 1994
}

\section{SUMMARY}

An investigation was made into the possible involvement of the enzyme xanthine oxidase (XO) (EC 1.1.3.22), both reversible (XOrev) and irreversible (XOirr), in damage observed after short-term in vivo hepatic ischaemia/reperfusion (60 or $120 \mathrm{~min} I$ and $15 \mathrm{~min} \mathrm{R}$ ) in fasted rats with: (i) a physiological content of XO (25\%); and (ii) higher XO percentage (45\%). In the latter the hepatic XO physiological percentage was increased by diethylmaleate treatment $\left(300 \mathrm{mg} \mathrm{kg}^{-1}\right)$ that depleted the cytosolic glutathione (GSH) to $14 \%$ of the controls. It was shown that, in animals with physiological content of XO, 60 and $120 \mathrm{~min}$ of hepatic ischaemia followed by $15 \mathrm{~min}$ reperfusion results in decreased GSH levels, and significantly increased alanine aminotransferase (ALT) and aspartate aminotransferase (AST) serum levels, without any modification of either the percentages of XO (XOirr and XOrev) or the hepatic thiobarbituric acid reactive substances (TBARS). Sixty minutes of ischaemia/reperfusion in rats with the higher XO level and lower hepatic GSH content led to further conversion of XDH to XOrev, with no increase in XOirr. In addition, the ALT and AST serum levels in these animals rose to the same extent as in normal rats after 120 min ischaemia and $15 \mathrm{~min}$ reperfusion, this extent being observed to be associated with a moderate increase in thiobarbituric acid reactive substances (TBARS). However, the administration of allopurinol, at a dose of $50 \mathrm{mg} \mathrm{kg}^{-1}$, which almost completely inhibits XO activity, did not lead to any decrease in liver damage or TBARS. These findings exclude any role of XO in liver damage in the short term following ischaemia/reperfusion events, also when marked GSH depletion could increase the enzymatic physiological XO level.

KEY WORDS: diethylmaleate, alanine and aspartate aminotransferase, thiobarbituric acid reactive substances.

\section{INTRODUCTION}

Liver transplantation and surgery involving the liver is complicated by ischaemia.

Correspondence to: Giuliana Cighetti, Department of Medical Chemistry and Biochemistry, University of Milan, Via Saldini 50, 20133, Milan, Italy. 
This has led to studies aimed at understanding the mechanism(s) of the structural damage that occurs $[1,2]$. In fact, although some researchers have proposed the involvement of oxygen free radicals [2-5], and the enzyme xanthine oxidase (XO) which is a possible source of these radicals [5-10], the mechanism of ischaemic tissue damage is still not fully understood. The involvement of $\mathrm{XO}$ was proposed after the observation that during reoxygenation following ischaemia, high doses of an XO inhibitor, allopurinol [11], limit cell damage [4, 12]. This hypothesis, on which much research in this field is based, is founded on reports that the enzyme, which in mammalian tissues exists predominantly as an $\mathrm{NAD}^{+}$reducing form (xanthine dehydrogenase, XDH), can be converted into two oxygen radicalproducing forms $(\mathrm{XO})$ by oxidation or by blocking the sulphydryl groups (reversible $\mathrm{XO}$, XOrev; reversed to $\mathrm{XDH}$ by dithiothreitol), or by limited proteolysis (irreversible XO, XOirr) [13-16]. However, recent studies have questioned this role of XO [17-19] and have proposed other sources for the toxic oxygen products and liver damage [20-23]. In fact, other studies have reported that the XDH conversion to XOrev or XOirr proceeds slowly and begins only after 2 or $3 \mathrm{~h}$ of hepatic ischaemia $[7,8,10,18]$, when the damage is already critical for normal functional recovery $[1,23]$.

The aim of this study was to evidence or exclude the possible involvement of $\mathrm{XO}$ in ischaemic liver damage in the period immediately following the onset of reperfusion. Thus, hepatic ischaemia and ischaemia/reperfusion experiments were performed on fasted normal rats and fasted rats with XO levels increased by the chemical depletion of their endogenous cytosolic glutathione (GSH), this depletion being obtained by i.p. administration of diethylmaleate (DEM) according to a model we have already reported [24]. Thus it could be expected that if $\mathrm{XO}$ is involved in hepatic ischaemia and reperfusion damage, such damage should be increased in rats with the high $\mathrm{XO}$ percentages and, in theory, could be prevented by inhibiting the $\mathrm{XO}$ activity. Furthermore, as it has been postulated that XOrev precedes the formation of XOirr $[8,25]$, the use of rats with increased XOrev levels makes it possible to anticipate the XOirr formation during ischaemia/reperfusion events.

Our results exclude any role of $\mathrm{XO}$ in ischaemic liver injury in a short period immediately after the onset of reperfusion. In fact, neither the rats with a physiological content of XOrev nor those with an increased XOrev content showed any formation of XOirr during ischaemia/reperfusion, and the extent of the damage observed was the same regardless of the XOrev or XOirr percentage present. In addition, similar amounts of released hepatic enzymes and thiobarbituric acid reactive substances (TBARS) were observed in all animals subjected to ischaemia/reperfusion, and also in those pretreated with moderate amounts of allopurinol which almost completely inhibits the total XO activity.

\section{MATERIALS AND METHODS}

\section{Chemicals}

Xanthine, uric acid, $\mathrm{NAD}^{+}$, dithiothreitol (DTT), leupeptin and other chemicals were purchased from Boehringer (Mannheim, F.R.G.); 2-thiobarbituric acid 
(TBA) was from Merck (Darmstadt, F.R.G.). Allopurinol (4-hydroxypyrazolo $[3,4,-d]$ pyrimidine), purchased from Aldrich Chimica S.r.l. Milano, was transformed into the sodium salt by treatment with a sodium hydroxide solution and then lyophilized. All other chemicals were of analytical purity.

\section{Animals and treatments}

The studies on ischaemia/reperfusion were carried out on male Sprague-Dawley rats $(200-250 \mathrm{~g})$, eight rats in each group. All the animals were fasted overnight for $15 \mathrm{~h}$, subjected to ischaemia (I) or ischaemia/reperfusion (I/R) and then decapitated between 8:00 and 9:00 hrs. The groups were:

(a) Normal controls: the rats were sham-operated, their vessels being manipulated but not clamped. The animals were killed in accordance with the times of those subjected to ischaemia.

(b) I and $I / R$ in normal rats: ischaemia and ischaemia/reperfusion injuries were induced as described below.

(c) $\mathrm{I} / \mathrm{R}(120 \mathrm{~min} / 15 \mathrm{~min})$ in normal rats treated with allopurinol $\left(50 \mathrm{mg} \mathrm{kg}^{-1}\right.$, i.p. $18 \mathrm{~h}$ and $60 \mathrm{~min}$ before liver reperfusion): the sodium salt of allopurinol corresponding to $200 \mathrm{mg}$ allopurinol was dissolved in $5 \mathrm{ml}$ of $0.9 \%$ saline solution; the i.p. administered volume was $0.25-0.3 \mathrm{ml}$.

(d) GSH-depleted controls: the rats were sham-operated $10 \mathrm{~min}$ after a single i.p. injection of DEM (300 $\left.\mathrm{mg} \mathrm{kg}^{-1}\right)$ [24].

(e) I and I/R in GSH-depleted rats: a single i.p. injection of DEM was made $10 \mathrm{~min}$ before ischaemia or ischaemia/reperfusion (explained below).

(f) $\mathrm{I} / \mathrm{R}(60 \mathrm{~min} / 15 \mathrm{~min})$ in $\mathrm{GSH}$-depleted rats pretreated with allopurinol (50 $\mathrm{mg} \mathrm{kg}^{-1}$ i.p. $18 \mathrm{~h}$ and $60 \mathrm{~min}$ before liver reperfusion) and with DEM (300 $\mathrm{mg} \mathrm{kg}^{-1}$ ) $10 \mathrm{~min}$ before ischaemia/reperfusion.

The animals subjected to partial hepatic ischaemia were lightly anaesthetized by diethyl ether. A midline incision was made in the abdomen and the hilar pedicle of the left lateral and median lobes was clamped off with a microvessel clip [26]. The abdomen was closed with silk sutures and the rats allowed to awaken. After 60 or $120 \mathrm{~min}$, the rats investigated for ischaemia were killed while those for ischaemia/reperfusion were reoperated to remove the clamp and killed $15 \mathrm{~min}$ after the restoration of the blood supply. The animals were killed by decapitation, their blood collected and the serum separated from the clotted blood by centrifugation at $3000 \mathrm{rpm}$ for $10 \mathrm{~min}$. For each rat the lateral and median lobes of the liver were pooled and used to determine the GSH and oxidized glutathione (GSSG) levels, and the TBARS and XO activity.

\section{Preparation of enzyme fraction and evaluation of total $(\mathrm{XDH}+\mathrm{XO})$ and $\mathrm{XO}$ activities}

The liver lobes were removed quickly, washed and homogenized in $50 \mathrm{~mm}$ phosphate buffer, pH 7.4, containing $1 \mathrm{~mm}$ EDTA $(1: 5, \mathrm{w} / \mathrm{v})$; the conversion of $\mathrm{XDH}$ to $\mathrm{XO}$ during handling was minimized by adding $10 \mathrm{~mm} 2$-mercaptoethanol, trypsin inhibitor $\left(5 \mathrm{mg} \mathrm{ml}^{-1}\right.$; type II-S from Sigma Chemical Co., Poole, U.K.) [27] and leupeptin $\left(0.5 \mathrm{mg} \mathrm{l}^{-1}\right)$ to the buffer before use. Instead of DTT, 2mercaptoethanol was added to the buffer as a thiol group protector as it prevents 
$\mathrm{XDH}$ to $\mathrm{XO}$ transformation, without promoting the conversion of $\mathrm{XO}$ to $\mathrm{XDH}$ [27]. The homogenate was centrifuged at $1500 \mathrm{~g}$ for $10 \mathrm{~min}$ and then at $105000 \mathrm{~g}$ for $60 \mathrm{~min}$ at $4^{\circ} \mathrm{C}$. The supernatant was dialysed for at least $4 \mathrm{~h}$ against the same homogenization buffer at $4^{\circ} \mathrm{C}$ [14]. Enzyme activity was measured by the method reported by Cighetti et al. [28] with small modifications. For the evaluation of total enzyme activity defined as $\mathrm{XDH}+\mathrm{XO}$, aliquots $(0.2 \mathrm{ml})$ of dialyzed enzyme fraction were preincubated for $30 \mathrm{~min}$ at $37^{\circ} \mathrm{C}$ in the presence of $10 \mathrm{~mm}$ DTT; diluted aliquots $(50 \mu \mathrm{g}$ protein) were then incubated after the addition of $60 \mu \mathrm{M}$ xanthine and $0.67 \mathrm{~mm} \mathrm{NAD}^{+}$for $10 \mathrm{~min}$ at $25^{\circ} \mathrm{C}$ (total volume $0.1 \mathrm{ml}$ ) [27]. DTT preincubation was carried out to transform the XOrev into XDH. XOirr and total $\mathrm{XO}$ (XOrev+XOirr) activities were determined in the absence of $\mathrm{NAD}^{+}$; for the evaluation of total XO activity, DTT activation was avoided. Values of XOrev activity were obtained by subtracting the XOirr value from that of total XO. Incubation was stopped by the addition of ethanol $(1 \mathrm{ml})$, the samples centrifuged at $1000 \mathrm{~g}$ for $5 \mathrm{~min}$ and the supernatants dried under nitrogen flow; the residues were resuspended in $0.1 \mathrm{~mm} \mathrm{NH} \mathrm{H}_{2} \mathrm{H}_{2} \mathrm{PO}_{4}, \mathrm{pH} 7(0.3 \mathrm{ml})$. Uric acid produced during the reaction was measured by HPLC (Lichrosorb, RP-18 reverse phase column, $0.1 \mathrm{~mm} \mathrm{NH}_{4} \mathrm{H}_{2} \mathrm{PO}_{4}, \mathrm{pH} 5.5$, mobile phase, $1.5 \mathrm{ml} \mathrm{min}^{-1}$ flow rate) [28], the peak being detected at $292 \mathrm{~nm}$. Total enzyme specific activity $(\mathrm{XDH}+\mathrm{XO})$ remained unchanged in all tested groups $(4 \pm 0.5 \mathrm{nmol}$ uric acid per min per $\mathrm{mg}$ protein) except for those treated with allopurinol. Each activity was expressed as a percentage \pm SE of total enzyme activity.

\section{Protein concentration}

Protein concentration was determined according to Bradford [29] using bovine serum albumin as a standard. The average protein content of the enzyme fraction was $12 \mathrm{mg} \mathrm{ml}^{-1}$.

\section{Thiol determination}

The total free (reduced and oxidized) and oxidized glutathione (GSSG) contents were assayed enzymatically in liver lobes homogenized in $0.1 \mathrm{M}$ phosphate buffer, $\mathrm{pH} 7.5$, containing 5 mм EDTA [30]. In the evaluation of the GSSG level, $10 \mathrm{~mm}$ $\mathrm{N}$-ethylmaleimide was added to the homogenization buffer to avoid GSH autooxidation.

\section{ALT and AST serum level}

The levels of serum alanine and aspartate aminotransferase (ALT and AST respectively) were measured on a Hitachi 747 discrete automatic analyser (Hitachi Ltd, Japan) with standard reagent supplied by Boehringer-Mannheim (Mannheim, Germany). Values are given as units per litre of serum.

\section{Assay of TBA reactive substances}

This assay was carried out as an index of biomolecule oxidant damage. The formation of thiobarbituric acid reactive substances (TBARS) was measured colorimetrically using 1,1,3,3-tetraethoxypropane as the external standard according to Ohkawa et al. [31]. Values are reported as nanomoles of 
Table I

Hepatic GSH and activity percentage of XO following in vivo rat liver ischaemia and reperfusion

\begin{tabular}{|c|c|c|c|c|c|c|}
\hline \multicolumn{2}{|c|}{ Treatment } & \multirow[t]{2}{*}{$A$} & \multirow{2}{*}{$\begin{array}{c}\text { GSH } \\
\left(\mu g \mathrm{mg}^{-1} \text { protein }\right)\end{array}$} & \multirow{2}{*}{$\begin{array}{c}\text { \% XO Total } \\
\text { (XOrev+XOirr) }\end{array}$} & \multirow[t]{2}{*}{$\%$ XOirr } & \multirow[t]{2}{*}{$\%$ XOrev } \\
\hline $\begin{array}{l}\text { Ischaemia } \\
\text { (min) }\end{array}$ & $\begin{array}{l}\text { Reflow } \\
\text { (min) }\end{array}$ & & & & & \\
\hline \multicolumn{7}{|l|}{ Normal } \\
\hline 0 & - & - & $12 \pm 1.0$ & $25 \pm 3$ & $18 \pm 1$ & $7 \pm 2$ \\
\hline 60 & - & - & $8 \pm 1.1^{*}$ & $23 \pm 2$ & $18 \pm 2$ & $6 \pm 1$ \\
\hline 60 & 15 & - & $6 \pm 0.6 *$ & $26 \pm 2$ & $18 \pm 1$ & $7 \pm 1$ \\
\hline 120 & - & - & $7 \pm 0.5 *$ & $25 \pm 1$ & $18 \pm 1$ & $5 \pm 1$ \\
\hline 120 & 15 & - & $5 \pm 1.0 *$ & $25 \pm 2$ & $18 \pm 1$ & $6 \pm 1$ \\
\hline 120 & 15 & + & $4 \pm 1.0 *$ & $<3 \ddagger$ & $<3 \div$ & $<3 \ddagger$ \\
\hline \multicolumn{7}{|c|}{ GSH-depleted rats } \\
\hline 0 & - & - & $1.7 \pm 0.1 *$ & $45 \pm 2 *$ & $23 \pm 0.5$ & $22 \pm 1 *$ \\
\hline 60 & - & - & $1.6 \pm 0.3 *$ & $70 \pm 3 \dagger$ & $23 \pm 1.0$ & $47 \pm 1 \dagger$ \\
\hline 60 & 15 & - & $1.2 \pm 0.1 *$ & $72 \pm 1 \dagger$ & $24 \pm 0.3$ & $48 \pm 2 \dagger$ \\
\hline 60 & 15 & + & $1.0 \pm 0.2 *$ & $<3 \div$ & $<3 \div$ & $<3 \div$ \\
\hline
\end{tabular}

Values of $\mathrm{XO}$ forms are expressed as percentage of total enzyme activity (XDH+XO) which was $4 \pm 0.5 \mathrm{nmol}$ uric acid per min per mg protein both in controls and GSH-depleted rats submitted (or not) to ischaemia and reperfusion.

A: + rats $(n=4)$ were treated with allopurinol $\left(50 \mathrm{mg} \mathrm{kg}^{-1}\right)$ i.p. $18 \mathrm{~h}$ and $1 \mathrm{~h}$ before liver reperfusion as reported in Materials and Methods; - rats untreated with allopurinol.

Each value is the mean $\pm \mathrm{SE}$ of triplicate determinations from eight rats.

$* \mathrm{p}<0.01$ vs normal fasted control rats.

$\dagger p<0.01$ vs GSH-depleted fasted control rats.

\$After allopurinol treatment, total enzyme activity $(\mathrm{XDH}+\mathrm{XO})$ was reduced to $0.12 \pm$ $0.05 \mathrm{nmol}$ uric acid per min per $\mathrm{mg}$ protein; corresponding to $3 \%$ of normal total activity.

malondialdehyde (MDA) per milligrams of protein and calculations were performed using a linear regression program.

\section{Statistics}

Data are expressed as means \pm SE and the statistical significance was determined using the Student's $t$-test.

\section{RESULTS}

Table I shows the hepatic levels of total free GSH (oxidized+reduced) and the percentage of the different forms of XO determined in all experimental groups. Normal fasted control rats showed GSH values in agreement with those previously observed [24]. When normal rats were submitted to 60 and $120 \mathrm{~min}$ in vivo ischaemia, the GSH levels reached, respectively, about $66 \%$ and $58 \%$ of that observed in the fasted control animals, and fell to $50 \%$ and $41 \%$ when ischaemia was followed by 15 min reperfusion.

The i.p. administration of DEM $\left(300 \mathrm{mg} \mathrm{kg}^{-1}\right), 10 \mathrm{~min}$ before inducing 
Table II

Evaluation of ALT and AST serum level and lipid peroxidation products following in vivo rat liver ischaemia and reperfusion

\begin{tabular}{|c|c|c|c|c|c|}
\hline \multicolumn{2}{|c|}{ Treatment } & \multirow[t]{2}{*}{$A$} & \multicolumn{2}{|c|}{$\operatorname{Serum}\left(U l^{-1}\right)$} & \multirow{2}{*}{$\begin{array}{c}\text { TBARS } \\
\text { (nmol MDA per } m g \\
\text { protein) }\end{array}$} \\
\hline $\begin{array}{l}\text { Ishaemia } \\
\text { (min) }\end{array}$ & $\begin{array}{c}\text { Reflow } \\
\text { (min) }\end{array}$ & & $A L T$ & $A S T$ & \\
\hline \multicolumn{6}{|l|}{ Normal } \\
\hline 0 & - & - & $73 \pm 2$ & $220 \pm 28$ & $1.2 \pm 0.1$ \\
\hline 60 & - & - & $80 \pm 3$ & $210 \pm 20$ & $1.1 \pm 0.2$ \\
\hline 60 & 15 & - & $500 \pm 30 *$ & $700 \pm 40 *$ & $1.0 \pm 0.1$ \\
\hline 120 & - & - & $95 \pm 4$ & $220 \pm 20$ & $1.0 \pm 0.3$ \\
\hline 120 & 15 & - & $1000 \pm 25 *$ & $1180 \pm 30 *$ & $1.1 \pm 0.1$ \\
\hline 120 & 15 & + & $1010 \pm 20 *$ & $1120 \pm 20 *$ & $1.0 \pm 0.2$ \\
\hline \multicolumn{6}{|c|}{ GSH-depleted rats } \\
\hline 0 & - & - & $85 \pm 5$ & $270 \pm 23$ & $1.3 \pm 0.2$ \\
\hline 60 & - & - & $156 \pm 6^{* \dagger}$ & $490 \pm 42 *+$ & $1.6 \pm 0.1$ \\
\hline 60 & 15 & - & $1225 \pm 50^{*} \dagger$ & $1670 \pm 60 *+$ & $3.5 \pm 0.6 * \leftarrow$ \\
\hline 60 & 15 & + & $1200 \pm 50 * \dagger$ & $1600 \pm 60^{*}+$ & $3.0 \pm 0.4^{*}+$ \\
\hline
\end{tabular}

$\mathrm{A}:+\operatorname{rats}(n=4)$ were treated with allopurinol $\left(50 \mathrm{mg} \mathrm{kg}^{-1}\right)$ i.p. $18 \mathrm{~h}$ and $1 \mathrm{~h}$ before liver reperfusion as reported in Materials and Methods; - rats untreated with allopurinol.

Each value is the mean \pm sE of triplicate determination.

$* p<0.01$ vs normal fasted control rats.

$t p<0.01$ vs GSH-depleted fasted control rats.

ischaemia, depleted the GSH level to $14 \%$ of that in the normal controls. This depleted level was not significantly modified by the following reperfusion nor by allopurinol treatment. No increase in the hepatic GSSG level (data not shown) was observed in any of the experimental groups (GSSG: $0.1-0.2 \mathrm{nmol}$ per $\mathrm{mg}$ protein), in agreement with the well documented relationship between intracellular GSSG and its efflux into bile [21].

As far as $\mathrm{XO}$ is concerned, the normal fasted control rats showed percentages of total XO (XOrev+XOirr; $25 \pm 3 \%)$ and XOirr $(18 \pm 1 \%)$ in agreement with previously reported values $[8,24,27]$ (Table I). Furthermore, in vivo ischaemia (60 or $120 \mathrm{~min}$ ) and ischaemia/reperfusion (60 or $120 \mathrm{~min} / 15 \mathrm{~min}$ ) caused no modification with respect to the controls. In accordance with previous results [24], the GSH-depleted controls showed a two-fold increase in the percentage of total $\mathrm{XO}(45 \pm 2 \%)$, and a three-fold increase in XOrev with respect to normal values. In these animals ischaemia caused a significant $(P<0.01)$ additional increase in total $\mathrm{XO}$ (XOrev+XOirr) compared with their control animals, due exclusively to an increase of XOrev. No additional increased in XOrev occurred during the following reperfusion. Irreversible $\mathrm{XO}$ was not affected by either ischaemia or reperfusion.

Allopurinol almost completely blocked the total enzyme activity (XDH+XO) in both normal and GSH-depleted rats subjected to ischaemia/reperfusion; in fact the activity fell from $4 \pm 0.5$ to $0.12 \pm 0.05 \mathrm{nmol}$ per min per $\mathrm{mg}$ protein. Due to the low total activity being equal to $3 \%$ of the normal value, the individual activity of the different $\mathrm{XO}$ forms was not measured but is reported in Table I as $<3 \%$. 
After ischaemia and ischaemia/reperfusion, liver damage was monitored by measuring serum ALT and AST levels while other damage attributable to oxidation of biomolecules was assayed as TBARS (Table II). In normal rats none of these parameters were affected after 60 and $120 \mathrm{~min}$ ischaemia. However, the ALT and AST serum values increased significantly after reperfusion with the increased duration of ischaemia, despite the pretreatment with allopurinol.

After $60 \mathrm{~min}$ ischaemia, the GSH-depleted rats, with their high XOrev values, showed a two-fold increase in serum ALT and AST values compared with normal rats; reperfusion for 15 min increased these values even further and they reached almost the same values as were observed in normal rats after $120 \mathrm{~min}$ ischaemia followed by $15 \mathrm{~min}$ reperfusion (Table II). However, normal and GSH-depleted rats pretreated with allopurinol and subjected to ischaemia/reperfusion showed no modification in ALT and AST serum values with respect to those not treated.

TBARS variations were observed only in the liver of DEM treated (GSHdepleted) animals after reperfusion, the levels appearing to be independent of any allopurinol pretreatment of the animals.

\section{DISCUSSION}

In the present study the conversion of XDH into XO (XOrev and XOirr) was studied after in vivo hepatic ischaemia and reperfusion in normal and GSHdepleted rats. The latter showed an enhanced content of liver XOrev that could be used to study the influence of the oxidized form of the XDH enzyme in liver damage.

Liver damage and the conversion of XDH to XOrev and XOirr were assessed after 60 and $120 \mathrm{~min}$ of hepatic ischaemia as such times represent the critical limits for normal functional recovery of ischaemic liver [1,23]. The above assessment was also made 15 min immediately after the onset of reperfusion to avoid any modification of XO due to the pathophysiological process that occurs in the late phases of reperfusion, and that could cause the conversion of XDH or XOrev to XOirr by proteolysis.

The experiments carried out on normal rats showed the GSH content to be depleted by up to $41 \%$ of the content in the controls during ischaemic episodes of $120 \mathrm{~min}$ or less, even in the cases where $15 \mathrm{~min}$ reperfusion was carried out. However, the XOrev and XOirr levels were unchanged, as was the total enzyme activity (Table I). In all of the experiments no variation in TBARS was observed, even in the presence of some hepatic enzyme (ALT and AST) leakage that occurred after 60 and $120 \mathrm{~min}$ ischaemia/reperfusion (Table II). However, the same release of hepatic enzymes was observed in rats pretreated with allopurinol which almost completely blocks the total xanthine oxidase activity, thus the leakage cannot be attributed to the presence of XO, but it could be from a different source and is probably favoured by an enhanced vulnerability of the hepatocytes due to GSH content depletion $[32,33]$.

Ischaemia and ischaemia/reperfusion experiments performed on rats with higher total XO levels than in normal rats led to the same conclusions. In fact, 60 min of ischaemia caused an additional increase in total XO from 45 to $70 \%$. 
This increase was due exclusively to XOrev since the XOirr percentage was unchanged (Table I). After restoration of the oxygen supply there was no further or new conversion of XDH or XOrev to XOirr, but there was a large release of hepatic enzymes similar to that found for normal rats $120 \mathrm{~min}$ after ischaemia/reperfusion. The only difference from normal rats was the increase in TBARS, showing higher tissue vulnerability. Thus, since the high percentage of XOrev was not followed by a comparable increase in the parameters that indicate liver injury, our results lead us to suggest that the conversion of XDH to $\mathrm{XO}$ during ischaemia is only a secondary event. However since there is the possibility that $\mathrm{XO}$ is responsible for accelerating liver damage and increasing TBARS, we performed ischaemia/reperfusion experiments on rats treated with both allopurinol and DEM. However, even in these conditions, where XO activity is almost completely blocked, there was still liver damage.

In conclusion, we have set up a simple experimental model that allows us to exclude any $\mathrm{XO}$ role in the liver damage observed in short-term hepatic ischaemia/reperfusion, also in rats with high XO levels and greatly depleted in GSH content.

\section{ACKNOWLEDGEMENTS}

This research was supported by a grant from the Ministero Università e Ricerca Scientifica e Tecnologica, Rome.

\section{REFERENCES}

1. Farber JL, Chien KR, Mittnacht S. The pathogenesis of irreversible cell injury in ischemia. Am J Pathol 1981; 102: 271-81

2. Granger DN, Rutili G, McCord JM. Role of superoxide radicals in intestinal ischemia. Gastroenterology 1981; 81: 22-9.

3. Granger DN, Hollwarth ME, Parks DA. Ischemia-reperfusion injury: role of oxygenderived free radicals. Acta Physiol Scand 1986; 126 (suppl 548): 47-63.

4. Adkinson D, Hollwarth ME, Benoit JN, Parks DA, McCord JM, Granger DN. Role of free radicals in ischemia-reperfusion injury to the liver. Acta Physiol Scand 1986; 548: $101-7$.

5. McCord JM. Oxygen-derived free radicals in postischemic tissue injury. N Engl J Med 1985; 312: 159-63.

6. Roy RS, McCord JM. Superoxide and ischemia: conversion of xanthine dehydrogenase to xanthine oxide. In: Greenwald RA, Cohen G, eds. Oxyradicals and their scavenger systems, vol II. New York: Elsevier, 1983: 145-53.

7. Engerson TD, McKelvey TG, Rhyne DB, Boggio EB, Snyder SJ, Jones HP. Conversion of xanthine dehydrogenase to oxidase in ischemic rat tissues. $J$ Clin Invest 1987; 79: $1564-70$.

8. McKelvey TG, Höllwarth ME, Granger DN, Engerson TD, Landler U, Jones PP. Mechanisms of conversion of xanthine dehydrogenase to xanthine oxidase in ischemic rat liver and kidney. Am J Physiol 1988; 254: G753-60.

9. Jaeschke H, Mitchell JR. Mitochondria and xanthine oxidase both generate reactive oxygen species in isolated perfused rat liver after hypoxic injury. Biochem Biophys Res Comm 1989; 160: 140-7. 
10. Brass CA, Narciso J, Gollan JL. Enhanced activity of the free radical producing enzyme xanthine oxidase in hypoxic rat liver. J Clin Invest 1991; 87: 424-31.

11. Elion GB, Kovensky A, Hitchings GH. Metabolic studies of allopurinol, an inhibitor of xanthine oxidase. Biochem Pharmacol 1966; 15: 863-80.

12. Nordstrom G, Seeman T, Hasselgren PO. Beneficial effect of allopurinol in liver ischemia. Surgery 1984; 97: 679-83.

13. Stirpe F, Della Corte E. The regulation of rat liver xanthine oxidase. Conversion in vitro of the enzyme activity from dehydrogenase (type D) to oxidase (type O). $J$ Biol Chem 1969: 244: 3855-63.

14. Della Corte E, Stirpe F. The regulation of rat liver xanthine oxidase. Involvement of thiol groups in the conversion of the enzyme activity from dehydrogenase (type D) into oxidase (type O) and purification of the enzyme. Biochem $J$ 1972; 126: 739-45.

15. Waud WR, Rajagopalan KV. The mechanism of conversion of rat liver xanthine dehydrogenase from an $\mathrm{NAD}^{+}$-dependent form (Type D) to an $\mathrm{O}_{2}$-dependent form (Type O). Arch Biochem Biophys 1976; 172: 365-79.

16. Battelli MG. Enzymic conversion of rat liver xanthine oxidase from dehydrogenase (D form) to oxidase (O form). FEBS Lett 1980; 113: 47-51.

17. Metzger J, Dore SP, Lauterburg BH. Oxidant stress during reperfusion of ischemic liver: no evidence for a role of xanthine oxidase. Hepatology 1988; 8: 580-4.

18. Marubayashi S, Dohi K. Yamada K, Kawasaki T. Role of conversion of xanthine dehydrogenase to oxidase in ischemic rat liver cell injury. Surgery 1991; 110: 537-43.

19. Karwinski W, Bolann B, Ulvik R, Farstad M, Soreide O. Normothermic liver ischemia in rats: xanthine oxidase is not the main source of oxygen free radicals. Res Exp Med 1993; 193: $275-83$.

20. Jaeschke H, Farhood A. Neutrophil and Kupffer cell-induced oxidant stress and ischemia-reperfusion injury in rat liver. Am J Physiol 1991; 260: G355-62.

21. Jaeschke H. Reactive oxygen and ischemic/reperfusion injury of the liver. Chem-Biol Inter 1991; 79: 115-36.

22. De Groot $\mathrm{H}$, Brecht $\mathrm{M}$. Reoxygenation injury in rat hepatocytes: mediation by $\mathrm{O}_{2} / \mathrm{H}_{2} \mathrm{O}_{2}$ liberated by sources other than xanthine oxidase. Biol Chem Hoppe-Seyler 1991; 372: $35-41$.

23. Gonzales-Flecha B, Cutrin JC, Boveris A. Time course and mechanism of oxidative stress and tissue damage in rat liver subjected to in vivo ischemia-reperfusion. J Clin Invest 1993; 91: 456-64.

24. Cighetti G, Debiasi S, Paroni R. Effect of glutathione depletion on the conversion of xanthine dehydrogenase to oxidase in rat liver. Biochem Pharmacol 1993; 45: 2359-61.

25. Nordback IH, Cameron JL. The mechanism of conversion of xanthine dehydrogenase to xanthine oxidase in acute pancreatitis in the canine isolated pancreas preparation. Surgery 1993; 113: 90-7.

26. Bernelli-Zazzera A, Gaja G. Some aspects of glycogen metabolism following reversible or irreversible liver ischemia. Exp Mol Pathol 1964; 3:351-68.

27. Battelli MG, Della Corte E, Stirpe F. Xanthine oxidase type D (dehydrogenase) in the intestine and other organs of the rat. Biochem $J$ 1972; 126: 747-9.

28. Cighetti G, Del Puppo M, Paroni R, Galli Kienle M. Lack of conversion of xanthine dehydrogenase to xanthine oxidase during warm renal ischemia. FEBS Lett 1990; 274: $82-4$.

29. Bradford MM. A rapid and sensitive method for the quantitation of microgram quantities of protein utilizing the principle of protein dye binding. Anal Biochem 1976; 72: 248-54.

30. Tietze F. Enzyme method for determination of nanogram amounts of total and oxidized glutathione. Anal Biochem 1969; 27: 502-22

31. Ohkawa H, Ohishi N, Yagi K. Assay for lipid peroxides in animal tissues by thiobarbituric acid reaction. Anal Biochem 1979; 95: 351-8.

32. Jennische E. Possible influence of glutathione on postischemic liver injury. Acta Path Microbiol Immunol Scand Sector A 1984; 92: 55-64.

33. Stein HJ, Oosthuizen MMJ, Hinder RA, Lamprechts $H$. Oxygen free radicals and glutathione in hepatic ischemia/reperfusion injury. J Surg Res 1991; 50: 398-402. 